\title{
Analysis of discourse features of an EFL Internet forum debate
}

Marti A. Dechesne

\section{(2) OpenEdition}

1 Journals

Electronic version

URL: http://journals.openedition.org/asp/4475

DOI: 10.4000/asp.4475

ISBN: 978-2-8218-0384-8

ISSN: 2108-6354

Publisher

Groupe d'étude et de recherche en anglais de spécialité

Printed version

Date of publication: 1 October 2001

Number of pages: 103-114

ISSN: 1246-8185

\section{Electronic reference}

Marti A. Dechesne, «Analysis of discourse features of an EFL Internet forum debate », ASp [Online] 31-33 | 2001, Online since 03 August 2014, connection on 10 December 2020. URL : http:// journals.openedition.org/asp/4475; DOI : https://doi.org/10.4000/asp.4475

This text was automatically generated on 10 December 2020.

Tous droits réservés 


\title{
Analysis of discourse features of an EFL Internet forum debate
}

\author{
Marti A. Dechesne
}

\section{Introduction}

1 The conversational aspects of synchronous Internet communication lend itself readily to discourse analysis research by the very nature of the medium; there is a written record of the communication exchange available that combines the listener speaker dyad and permanent documentation for analysis. Synchronous communication is conversational exchanges that occur in real time such as chats: synchronous communication is delayed communication exchanges, a message is sent and then picked up or read at a later time by the concerned parties. Asynchronous communication has the advantage over synchronous communication in an e-mail format because it is immediate. The students must respond rapidly and apply both acquired English skills and communication strategies to comprehend and react quickly. Because the students are responding in real time, there is no time to analyze grammatical correctness or do a check for spelling errors before sending the message, which is what one has the time to do before sending off an e-mail message.

2 An Internet debate was set up between the Universidad Politecnica de Valencia (The Polytechnic University of Valencia, Spain) and the Université de Nice-Sophia Antipolis (University of Nice, France) as a collaboration in the IDEELS project (Intercultural Dynamics in European Education through on-line Simulation). ${ }^{1}$ Although project IDEELS is a collaborative project utilizing both synchronous and asynchronous communication to complete a scenario, the Internet debate was constructed as a preliminary project outside the normal project IDEELS scenarios.

3 The purpose of the Internet forum debate was to provide a practical application of the Internet skills learned in the English Through Internet course developed by the author as part of the English certification requirement at the University of Nice (Dechesne 1999). 
The Internet format provided an excellent forum for the students to practice not only their English skills in a real situation through written communication, but also to put into practice their computer skills learned in the class.

\section{Literature review}

4 Discourse analysis "examines the way in which sentences are combined in larger linguistic units such as conversational exchanges or written texts" (ERIC 1986: 3) and usually involves the context involved which goes beyond the sentence level (Karasavvidis 2000). Electronic discourse analysis can be either synchronous or asynchronous; can include discussion groups and email; and has elements of written and spoken discourse (Davis 1997). From the research of Chun (1994) and Kern (1995) it appears that students spend more time on-task during synchronous electronic discourse than with ordinary classroom discourse and there is less teacher domination which affords increased student production of more complex language. Sotillo investigated the discourse functions and syntactic complexity of communication exchanges via two modes: asynchronous and synchronous. She found that discourse function in asynchronous discussion was "more constrained than those found in synchronous discussions and similar to the... traditional language classroom" whereas synchronous discourse was "similar to the types of interactional modifications found in face-to-face conversations" (2000: 1).

Discourse analysis can take place at the level of the utterance as a unit of speech communication. Bakhtin notes

the fact is that when the listener perceives and understands the meaning (the language meaning) of speech he simultaneously takes an active, responsive, attitude towards it. He either agrees or disagrees with it, augments it, applies it, prepares for its execution [...]. (1986: 69)

Sotillo (2000) defined the units for discourse analysis which encoded specific functions: greetings, topic initiation moves, assertions and/or imperatives, requests, responses, adversarial moves, off topic moves, topic shifts, humor, requests for information, floor holding moves, corrective feedback, reprimands, and closings. December (1996) focused on media characteristics in defining units of analysis for Internet communication research.

\section{Methodology and procedures}

\section{Description of Participants}

7 In Valencia 12 students were involved, ranging in age from 20-22 years old. They were third and fourth year telecommunication engineering students from a large intermediate English class who volunteered to participate in the debate outside of their regular class schedule. The students were divided into 4 teams: Lilac, Gold, Green, and Indigo. In Nice there were 19 students who participated as a course requirement during regular English through Internet class time. They were all second semester freshmen students in their late teens and early 20s who were majoring in psychology. The students were divided into four teams: Navy, Olive, Red, and Teal.

The debate was monitored by three professors: The Forum moderator, Dr. Janet Sutherland, IDEELS project coordinator in Germany who chaired the debate and was 
online with the students and guided the discussion; Dr. Frances Watts, who was on-hand in Valencia to provide any necessary assistance for her students throughout the debate, and Dr. Marti Dechesne who oversaw the debate from Nice for her students.

\section{Methodology}

9 The 90 minute debate took place in April 2000. The topic of the debate was decided in advance by the professors involved during an IDEELS project meeting in Valencia in September 1999. The topic of the debate as presented to the students was "Education is expensive. Let's talk about how we would balance the education budget: should students pay (or pay more), or should universities accept fewer students?... What is the current situation in your country ?... Consider these two options: fewer students or higher fees... Any alternatives?"

Students from both universities were presented with the topic two weeks in advance of the scheduled debate. At this time the concept of PMI (Plus, Minus, Interesting) was discussed as a brainstorming method. Students were asked to structure their debate in terms of what would be a plus, what would be a minus, and what would be interesting as an outcome of their stance on the debate issue. The teams from Valencia, according to Dr. Watts had about 30-40 minutes in class to brainstorm, then worked in teams of two on the computer to compose a position on the topic (writing at least 1-2 sentences per point of discussion) during an additional hour. After class students met to refine their positions and the day of the debate brought their written discussion on a floppy disk. Students arrived fifteen minutes in advance of the scheduled debate time to become familiar with the OPUSi software, and to group into four teams of three members. During the debate, students were able to cut and paste their previously written messages or make slight modifications according to the agenda. For the debate the Spanish teams were designated as: Gold, Green, Indigo and Lilac.

In Nice the teams met for about 30 minutes in class to brainstorm possible questions to pose to the opposing university and possible responses to questions the others might ask. Four teams were formed with four or five students per group. In addition they met once outside class time to refine their positions and to put their ideas into writing but not on diskette. Students were only able to familiarize themselves with the OPUSi software at the beginning of the debate and therefore spent the introductory moments learning the operational features. The French teams were: Navy, Olive, Red and Teal.

\section{Data analysis}

\section{Distribution of responses}

12 As the OPUSi software allows a printout of requested data, a permanent record of the debate was available for analysis. Data analysis included specific distribution of responses and also study of discourse analysis behavioral categories.

13 The total number of responses was fairly evenly distributed among the three groups. Spain had a total of 116 responses with an average of 29 , France's total contributions were 108 with an average of 27, and the Moderator had a total of 32. In Figure 1 the breakdown of responses of all participants is shown. 
Figure 1. Responses by debate teams and moderator

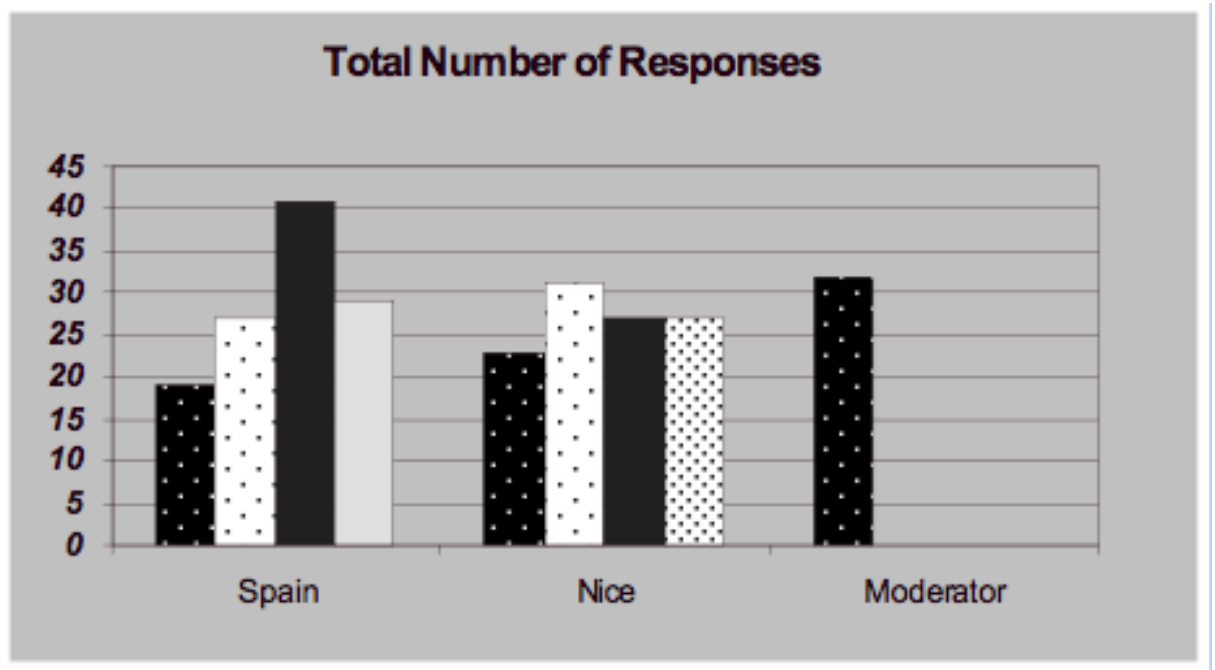

14 There were four teams from Spain (Lilac, Gold, Green, Indigo) and Nice (Navy, Olive, Red, Teal).

15 The distribution of messages was of interest not only in the total amount but the relevancy. Were the participants on task? The majority of responses by all students and the moderator were on topic throughout the debate. (See Figure 2). There was a software feature that allowed secret messages to be sent to a particular team which were only visible to that team and to the moderator. The Olive French team used this feature for $11 \%$ of their messages, which appeared to have been a mechanism for coping with the speed and complexity of the debate.

Figure 2. Percentage of messages according to distribution of tasks.

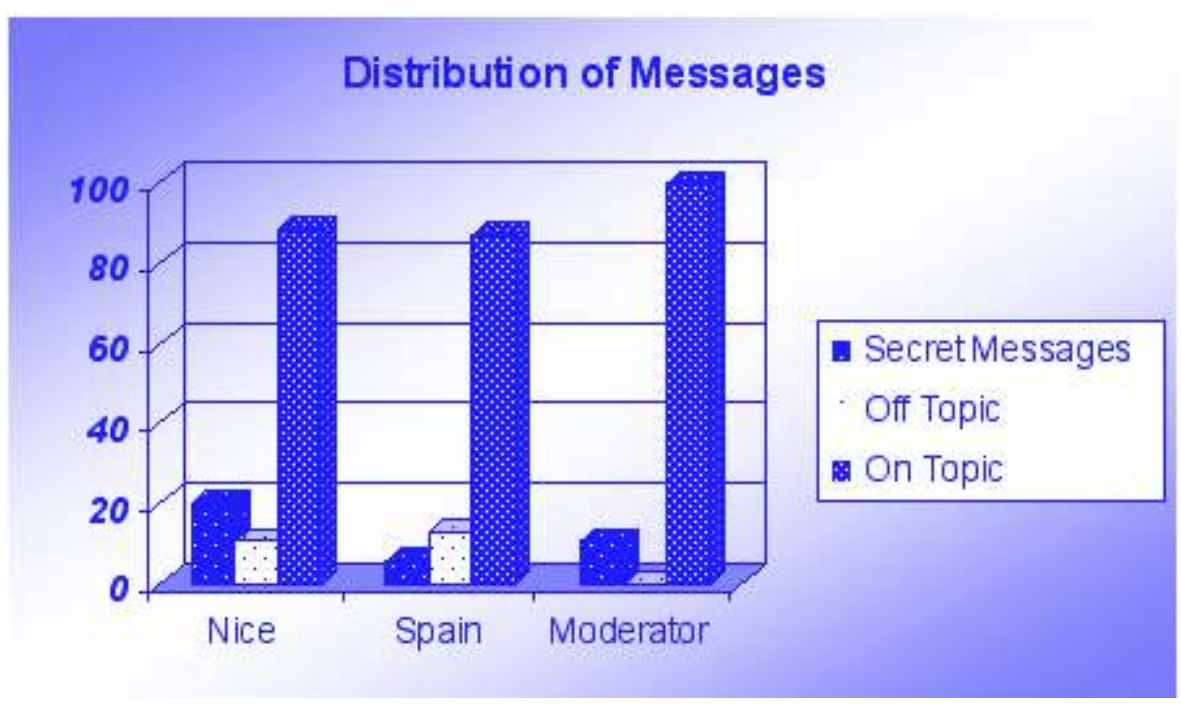

\section{Discourse analysis behavioral categories}

A discourse analysis was completed based on the following categories: social conventions, questions, responses, discussion offerings. 
The first category, Social Conventions, includes those discourse features that make conversations more courteous. In the following table (Table 1) discourse features are listed along with examples from all participants (French team, Spanish team and moderator) to clarify the categories. In this first category a great deal of the social conventions naturally occur in the beginning with greetings and with general comments before taking part in the specifics of the debate. Another feature that is often employed in conversational exchanges is tone setting whereby the speaker usually attempts to convey a positive reinforcing tone in greetings but also when politely disagreeing, redirecting or terminating a conversation.

Table 1. Social conventions

\begin{tabular}{|c|c|}
\hline Discourse Features & Examples \\
\hline Greetings & $\begin{array}{l}\text { Good morning to everyone. } \\
\text { Welcome Valencia. } \\
\text { We're pleased to meet you. }\end{array}$ \\
\hline Partings & $\begin{array}{l}\text { Goodbye. } \\
\text { Byebye. } \\
\text { Bientot. }\end{array}$ \\
\hline Thank yous & $\begin{array}{l}\text { Thank you. } \\
\text { We appreciate your discussion with us. } \\
\text { Thanks for the tip. }\end{array}$ \\
\hline Apologies & Sorry but... \\
\hline General: health, weather & $\begin{array}{l}\text { Maybe you could tell me what the weather is like? } \\
\text { It's raining cats and dogs. }\end{array}$ \\
\hline Tone setting & $\begin{array}{l}\text { We are happy to debate with you. } \\
\text { I'm glad to hear that. } \\
\text { It seems to be interesting. } \\
\text { That's a good question. } \\
\text { We hope we will have a good time. }\end{array}$ \\
\hline
\end{tabular}

18 In the second category, the types of Questions used are classified according to specific question functions (Table 2). Questions include the simple demand to make things clearer, the desire for more information, and as a technique to continue the debate by asking an on-topic question.

Table 2. Questions

\begin{tabular}{|l|l|}
\hline Discourse Features & Examples \\
\hline Clarification request & So, the subject is about the money at university, isn't it? \\
\hline
\end{tabular}




\begin{tabular}{|l|l|}
\hline Request for information & Have you enough places for everyone who wants study? \\
\hline $\begin{array}{l}\text { Consensus Request (general } \\
\text { agreement) }\end{array}$ & Yes, let's begin, no? \\
\hline $\begin{array}{l}\text { Main topic continuation (on } \\
\text { topic question) }\end{array}$ & $\begin{array}{l}\text { Do you think that your level of education will decrease if } \\
\text { you pay some fees to study? }\end{array}$ \\
\hline Technical help & $\begin{array}{l}\text { Is there way to make the messages stop scrolling all the } \\
\text { time? }\end{array}$ \\
\hline
\end{tabular}

19 In the Response Category, the statements in the debate were often in response to direct questions but they also were related to other statements or messages as one would expect from a debate format. Messages should usually refer to previous messages or questions in order to keep the debate or discussion evolving. In Table 3 the dispersal of response categories are delineated. Because the text box scrolls down with every message sometimes by the time a team types and sends their response or comment to a specific message, their message may appear far from the original, thus resulting in occasional unclear referents.

Table 3. Responses

\begin{tabular}{|l|l|}
\hline Discourse Features & Examples \\
\hline $\begin{array}{l}\text { Simple rejoinder (answer to a } \\
\text { specific question) }\end{array}$ & $\begin{array}{l}5 \text { years } \\
\text { Research projects and cooperations with companies. }\end{array}$ \\
\hline $\begin{array}{l}\text { Elaboration, explanation, } \\
\text { clarification }\end{array}$ & $\begin{array}{l}\text { Everybody has the right to go to the faculty. } \\
\text { It is interesting to go to the fac because it is a different } \\
\text { environment for the students. }\end{array}$ \\
\hline $\begin{array}{l}\text { Opinion statements } \\
\text { We disagree with your opinion. } \\
\text { We are agree with the Green Team. }\end{array}$ \\
\hline Teriginal message) & $\begin{array}{l}\text { Type your message first, then click on the "Make your } \\
\text { statement" button. }\end{array}$ \\
\hline
\end{tabular}

20 The last category refers to Discussion items and how they related to the debate (See Table 3). Some remarks were not made in direct reference to other messages but were simply offered as part of the discussion in continuation of the topic. They were more like an offering for discussion than an exchange. Some discussion items were elaborations or an attempt to introduce a related subtopic. When the students were discussing the cost of books, a related subtopic of photocopying textbooks to reduce costs was brought up. The Olive French team had the most off-topic discussion messages. 
Table 4. Discussion

\begin{tabular}{|l|l|}
\hline Discourse Features & Examples \\
\hline $\begin{array}{l}\text { Main Topic (MT) -debate offering } \\
\text { or continuation of the main topic }\end{array}$ & $\begin{array}{l}\text { The problem is that the government doesn't do enough } \\
\text { investments to make possible a free university for } \\
\text { everybody. }\end{array}$ \\
\hline $\begin{array}{l}\text { Elaboration, } \\
\text { clarification }\end{array}$ & $\begin{array}{l}\text { In France, the high school is not expensive for inscription } \\
\text { and social security we paid between 303 Euros and } 485 \\
\text { Euros. 1Euro = 6.60 francs. }\end{array}$ \\
\hline Subtopic initiation & $\begin{array}{l}\text { Here are expensive too. But we make photocopies of the } \\
\text { library book. }\end{array}$ \\
\hline $\begin{array}{l}\text { Rebuke (not a real request for } \\
\text { information) }\end{array}$ & $\begin{array}{l}\text { Do you live on this planet? } \\
\text { Well ,well, well. We are trying to return to our topic. }\end{array}$ \\
\hline off topic & $\begin{array}{l}\text { Our names are..... } \\
\text { Yes, we don't love the king, we are republican people. }\end{array}$ \\
\hline Redirect & $\ldots$ getting back to the topic.... \\
\hline
\end{tabular}

\section{Discourse feature distribution}

21 Analysis of the discourse features used by the French teams, the majority of the Navy Team's messages were responses to posed questions and were either simple rejoinders or elaborations. They were always on topic and had no secret messages. For the Red Team, the preponderance of messages was in the discussion category and was simple debate offerings. They had only 3 off-topic messages and 2 secret messages. For the Teal Team the bulk of contributions fell in the social conventions category followed by discussion offerings. There were no secret messages and they were always on topic. In the last team, the Olive's discussion was divided between questions and responses but $71 \%$ of them were off-topic and they sent 22 secret messages. Figure 3 presents the percentages of discourse category features by team and Figure 4 notes the total number of responses in each category by discourse features. Although the Olive team had a fairly even distribution of responses among the categories, most of the offerings were off-topic. 
Figure 3. Discourse features distribution within each of the French teams

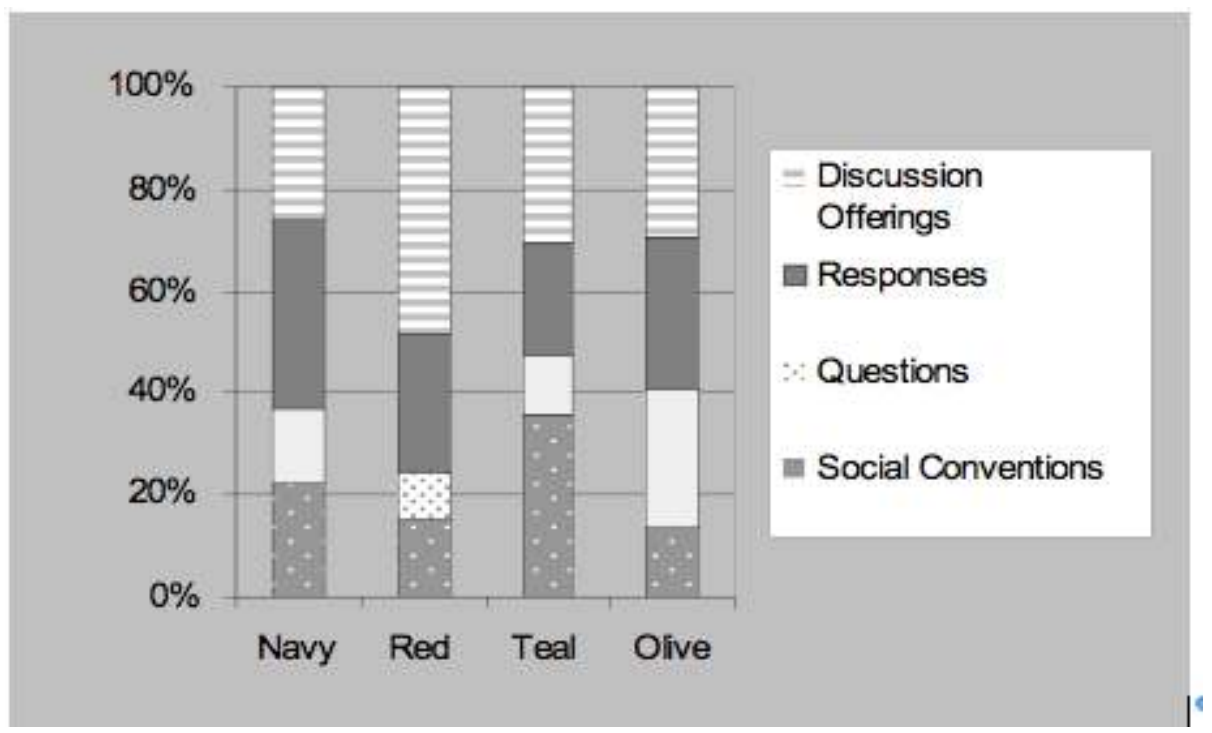

Figure 4. Total number of responses by French teams in each of the discourse feature categories

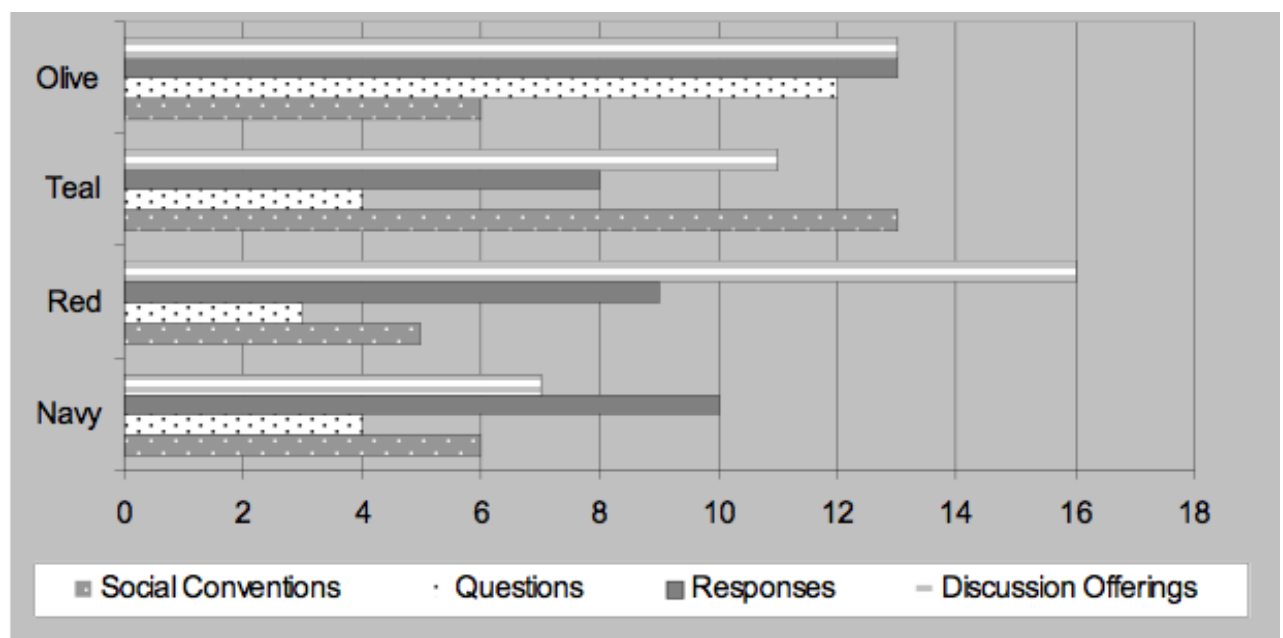

Regarding the Spanish teams, the majority of the Indigo team's responses were discussion offerings and were predominantly Main Topic (MT) continuations. Although eleven responses were off topic, this team had the most total responses. The Lilac team's responses were mostly debate offerings. They sent only 3 secret messages, all of which were off topic. The major portion of the Gold team's communication was MT debate offerings, three of which were off topic. They sent no secret messages. The Green team messages were generally MT debate offerings with no secret messages and only 2 off topic remarks. Figure 5 shows the distribution of categories by team while Figure 6 indicates the distribution of quantity for each of the categories.

Figure 5. Discourse features distribution within each of the Spanish teams 
Figure 6. Total number of responses by Spanish teams in each of the discourse feature categories

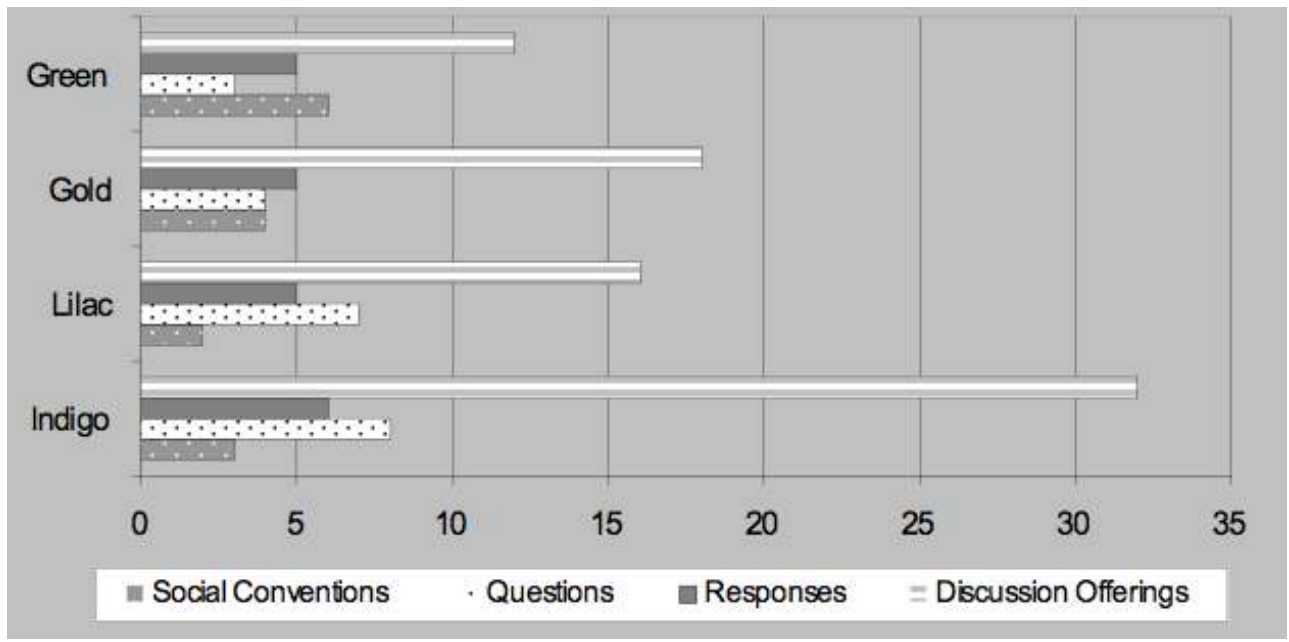

The forum moderator was more balanced among the discourse feature categories that she used which could be attributed to her role as moderator. She had a fairly even distribution among Social Conventions, Questions and Discussion Offerings. There were fewer messages in the discourse feature of Responses, mainly due to her function as monitor of the debate, not as a full participant. In Figure 7 the distribution among the discourse features is delineated.

Figure 7. Discourse features distribution for the Moderator

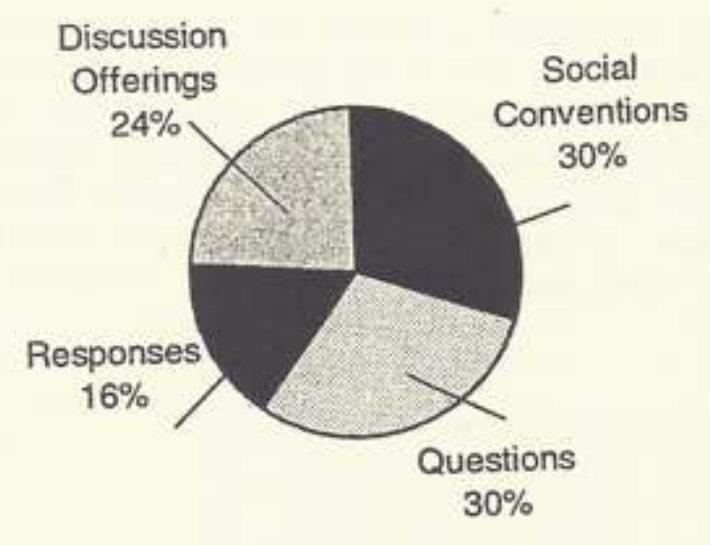

\section{Discussion and recommendations}

At the beginning of this project, one aspect under consideration was the analysis of the linguistic and syntactical complexity of the language used in this synchronous communication discussion using T-units similar to the work done by Sotillo (2000). The appropriateness of utilizing this technique was hampered by two factors. Due to the medium of synchronous communication there is a need to respond simply and quickly in order to keep up with the ongoing debate. A cursory evaluation of the printout noted that sentence and response length were very similar among the teams of the two universities. Occasionally longer and more complex sentences would appear perhaps because during 
the preplanning phase, the Spanish teams were advised to type out their possible responses beforehand and simply cut and paste the desired phrases from their diskettes into the debate messages. This would no longer be synchronous discussion as it would allow the writer to edit and revise the response and therefore allow longer or more complex contributions. There was no way of knowing which of the messages were spontaneous and which were previously composed, therefore it would be impossible to distinguish if the grammatical complexity could be attributed to ability or to editing opportunities.

Synchronous communication is "chat-like" in that the participants write responses without taking the time to check the spelling and grammar and are more interested in communicating a message. Synchronous communication becomes more like spoken discourse. Evidence of this was noted in the analysis of discourse features that were used by the two universities. Whereas the Spanish team had more Main Topic discussion offerings, the Nice teams used a wider variety of discourse functions including asking questions, requesting more information, responding to information, using social conventions, and reacting to the information presented in the debate. The Spanish team more often presented information that was certainly on the topic, but not as often in reaction to previous messages or a conversational exchange. This may be attributed to the fact that the Spanish team composed many of the messages on disk and pasted them where they fit during the debate.

The moderator played an important role in the debate by introducing new concepts or discussion points. These did not necessarily generate a reaction by all teams, but her function was to keep the discussion generally on topic and to facilitate the debate as a neutral participant. There was no need to encourage participation as there was no break in the debate during the full 90 minutes.

The feature of the secret message allowed the one French team to participate on a different level, as they became quickly overwhelmed with the speed and grammatical complexity of the debate responses. Although they did not comply with the requested task of debating the question of educational and economic priorities within the university systems in France and Spain, they nevertheless were able to join in the discussion at their own level by sending secret messages to several teams. The other teams and the moderator gave no evidence of being unduly agitated or disturbed by their alternative level of participation.

Several factors contributed to the success of the Internet debate. The purpose of the debate was well defined in advance, the students were given time to prepare and research possible responses and questions, adequate time was allotted for the debate itself and there was a monitor in each location and someone responsible overall for the running of the debate. The debate could be evaluated as being highly successful in light of the fact that the French team fulfilled their purpose of practicing their synchronous communication skills in a real situation and both the French and Spanish teams requested another opportunity to participate in a future Internet debate.

There are many practical applications of this Internet debate technique for classroom purposes other than just employing skills learned in a computer-based classroom. A debate could be set up, either inter- or intranet (a local connection among computers in a room or on a campus) that would stimulate discussion targeting a particular grammatical structure by the nature of the task. If the purpose was to practice the future tense, the 
topic of the debate could be future goals or aspirations of the participants. If the target structures were passives or reported speech, the topic could be duly adapted. Specific content skills could be practiced by initiating a topic debate relevant to the students area of study: a specific court scenario, necessary features of a machine to manufacture an invented product, a points of view concerning patient rights.

Pedagogically this technique of an Internet forum debate could also be exploited for different functions. Synchronous discussion would encourage spontaneous usage whereas asynchronous formats allow the user to revise and edit productions before sending. As the world becomes smaller and smaller due to the increasing availability of Internet connections, students can not only communicate with others in the same room, they can also collaborate with students in another country. Success of the technique depends on thoroughly understanding the purpose, the software, and the task at hand. Having sufficient time to prepare through group discussion or individually enhances the success of an Internet forum debate.

\section{BIBLIOGRAPHY}

Bakhtin, M.M. 1986. Speech Genres and Other Late Essays. Austin, TX: University of Texas Press.

Chun, D. 1994. "Using computer networking to facilitate the acquisition of interactive competence". System 22, 17-31.

Davis, B. 1997. Electronic Discourse: Linguistic Individuals in Virtual Space. New York: State University of New York Press.

December, J. 1996. “Units of analysis for Internet communication”. Journal of Communication 46/1. Available at <http://www.ascusc.org/jcmc/vol1/issue4/ december.html>.

Dechesne, M. 1999. “Un nouveau système de certification en langues. ASp 23-26, 571-578.

ERIC Clearinghouse on Languages and Linguistics. 1986. "What is linguistics?”. District of Columbia: US Dept. of Education. Available ERIC document: ED278255.

Karasavvidis, I. 2000. “Discourse - Qualitative Discourse Analysis”. Available at <http:// www.geocities.com/Athens/Crete/3011/Discourse_Qualitative.html>.

Kern, R. 1995. "Restructuring classroom interaction with networked computers: Effects on quantity and quality of language production". Modern Language Journal 79, 457-476.

Sotillo, S. 2000. "Discourse functions and syntactic complexity in synchronous and asynchronous communication". Language Learning \& Technology 4/1, 82-119.

\section{Bibliographie complémentaire}

Hegelheimer, V. \& C. Chapelle. 2000. "Methodological issues in research on Learner-computer interactions in CALL". Language Learning \& Technology 4/1, 41-59.

Mitra, A. 1999. "Characteristics of the WWW text: Tracing discursive strategies". Journal of Computer-Mediated Communication 5/1. Available at <http://www.ascusc.org/jcmc/vol5/issue1/ mitra.html>. 
Turoff, M. et al. 1999. "Collaborative discourse structures in computer mediated group communication". Journal of Computer-Mediated Communication 4/4. Available at <http:// onlinelibrary.wiley.com/doi/10.1111/j.1083-6101.1999.tb00104.x/full>.

\section{NOTES}

1. Further information concerning the project IDEELS can be obtained from the project website: $<$ http://www.ideels.uni-bremen.de>.

\section{ABSTRACTS}

As part of a collaboration with the IDEELS project, an Internet forum debate was organized between the students at a university in Valencia, Spain and students at the Université de Nice, France. The forum debate was mediated by the IDEELS (Intercultural Dynamics in European Education through on-Line Simulation) project manager at a university in Germany. The discourse data collected from the debate was analyzed according to the following behavioral categories: social conventions, questions, responses, and discussion offerings. Members of the debate utilized different sets of strategies to cope with the rapidity and complexity of the task.

Un débat sur l'Internet a été mis en place en avril 2000 entre l'Université de Valencia et l'Université de Nice-Sophia Antipolis comme un travail collaboratif dans le cadre du projet IDEELS (Intercultural Dynamics in European Education through on-Line Simulation). Le débat a été dirigé par le directeur du projet IDEELS dans une université en Allemagne. L'analyse du discours a été effectuée dans les domaines suivants: conventions sociales, questions, réponses et offres de discussions. Les membres de ce débat ont utilisé des stratégies variées pour comprendre rapidement les conversations en direct avec les étudiants espagnols de niveau supérieur en anglais.

\section{INDEX}

Keywords: discourse analysis, electronic discourse, intercultural communication Mots-clés: analyse du discours, communication interculturelle, discours électronique, Internet

\section{AUTHOR}

\section{MARTI A. DECHESNE}

Marti Dechesne a obtenu sa qualification de maître de conférences cette année. En attendant un poste, elle enseigne l'anglais à l'Institut de formation de l'entreprise de la Chambre de commerce (Nice). L'année dernière, elle était Assistant Professor à Al Akhawayn University au Maroc.

Auparavant, elle avait un poste d'ATER à l'Université de Nice-Sophia Antipolis. Ses domaines de 
recherche sont l'application des nouvelles technologies, l'analyse du discours et l'évaluation des programmes. MartiCarros@aol.com 